Sección central 


\section{El trapo rojo, un faro de colores y la fiesta: un mundo de símbolos}

\author{
Artículo de investigación \\ Recibido: 5 de junio de 2020 \\ Aprobado: 8 de octubre de 2020 \\ Marcos González Pérez \\ Intercultura, Colombia \\ margonza1marcos@gmail.com
}

Cómo citar este artículo: González Pérez, Marcos (2021). El trapo rojo, un faro de colores y la fiesta: un mundo de símbolos. Estudios Artísticos: revista de investigación creadora, 7(10) pp. 48-65.

DOI: https://doi.org/10.14483/25009311.17512

$<$

Pájaro (2020). Fotografía: Biólogo.

Marco Daniel González Santoro.

\section{Resumen}

Los símbolos hacen parte de las manifestaciones sociales y dan cuenta de las complejidades en que están inmersas las comunidades humanas. Este ensayo busca explicar las diversas formas en que colectivos o individuos hicieron público los problemas que afrontaban al inicio del periodo de la cuarentena en Colombia, específicamente en el mes de marzo de 2020. En una especie de juego de colores, colgaron trapos rojos para llamar la atención sobre sus necesidades económicas, trapos negros para denunciar la violencia contra las mujeres o trapos azules para reclamar respeto por los trabajadores de la salud. Esa gama de símbolos cruzó fronteras y les dio visibilidad a todas estas problemáticas. De esta situación no escapó la fiesta, y este escrito trata de descifrar las diversas formas en que esta manifestación patrimonial podría ser defendida frente a la pandemia desencadenada por el coronavirus.

\section{Palabras clave}

Símbolos; colores; imaginarios; protesta; complejidad social; incertidumbre

\section{The Red Cloth, a Colorful Lighthouse and Festivities: a World of Symbols}

\footnotetext{
Abstract

Symbols are part of social manifestations and they give an account of the complexities that surround human communities. This essay seeks to explain the various ways that groups or individuals made public the problems they faced at the beginning of the quarantine period in Colombia, specifically during March 2020. In a kind of color game, they hung up red rags to call attention to their economic
} 
needs, black rags to denounce violence against women or blue rags to demand respect for health workers. This range of symbols crossed borders and gave visibility to all of these issues. From this dire situation festivities did not escape, and this essay tries to decipher the various ways in which this patrimonial manifestation can be defended against the pandemic triggered by the coronavirus.

\section{Keywords}

Symbols; colors; imaginary; protest; social complexity; uncertainty

\section{Le chiffon rouge, un phare coloré et des festivités : un monde de symboles}

\section{Résumé}

Les symboles font partie des manifestations sociales et rendent compte des complexités qui entourent les communautés humaines. Cet essai cherche à expliquer les différentes manières dont des groupes ou individus ont rendu publics les problèmes auxquels ils étaient confrontés au début de la période de quarantaine en Colombie, plus précisément en mars 2020. Dans une sorte de jeu de couleurs, ils ont accroché des chiffons rouges pour attirer l'attention sur leurs besoins économiques, des chiffons noirs pour dénoncer la violence contre les femmes ou des chiffons bleus pour exiger le respect des agents de santé. Cette gamme de symboles a franchi les frontières et a rendu visible l'ensemble de ces enjeux. De cette situation désastreuse, les festivités n'ont pas échappé, et cet écrit tente de décrypter les différentes manières dont cette manifestation patrimoniale pourrait être défendue contre la pandémie déclenchée par le coronavirus.

\section{Mots clés}

Symboles; couleurs; l'imaginaire ; manifestation; complexité sociale ; incertitude

\section{O pano vermelho, um farol de cores e a festa: um mundo de símbolos}

\section{Resumo}

Os símbolos fazem parte das manifestações sociais e dão conta das complexidades nas quais estão imersas as comunidades humanas. Este ensaio busca explicar as diversas formas pelas quais coletivos humanos ou indivíduos tornaram público os problemas que afrontavam o início do período da quarentena na Colômbia, especificamente no mês de março de 2020. Numa espécie de jogo de cores, penduraram panos vermelhos para chamar a atenção sobre as necessidades de apoio contra suas pobrezas, ou panos pretos para denunciar a violência contra as mulheres, ou panos azuis para reivindicar respeito aos trabalhadores da saúde. Esta gama de símbolos cruzaram fronteiras até fazer visíveis todas problemáticas. Desta situação, não escapou a festa, tema que também aborda este escrito tratando de decifrar as diversas formas de se defender contra a pandemia produzida pelo vírus covid 19, esta manifestação patrimonial.

\section{Palavras chave}

Símbolos, cores, imaginários, protesto, complexidade social, incerteza

\section{Sug Puka linso, awapi churaska subrigcha linsukunaua tukuikunata kauachiku ministidukuna}

\section{Maillallachiska}

Ninakumi kai linsukuna churaspa Munanaku kauachinga kanchanimandakunata ima iakikuna tiaska kai, mailla kilkapi nikumi, kai wata kaiarinakura marzo killa tukuikuna iukaskanchi ukuma wichakaringa, chiura llapa iakiikuna challaska wasikunama , sugkuna Puka linsu churaskakuna mañangapa mikui, sug nuna sug linsu llana, warmikunadifindingapa, chasallata sugkuna linsu azul ambidurkunamanda ningapa ministinakumi Achka kulki kaugsangapa. Chasa tiami llapa atun llakiiku, kai jiru ungui covid 19.

\section{Rimangapa Ministidukuna}

Ima munaska kauachii; Achka linsukuna,iuiaria,rurakunaullariska; llapa llakiska; imaura tukunringapa; iakiikuna 


\section{El trapo rojo}

Rey: ¿Cuál es el día más largo que existe? Bertoldo: El día en que uno no come.

(Piero Camporesi, 2006)

Mientras transcurre el periodo de la cuarentena nacional, decretada por el gobierno central (marzo a mayo, 2020) buscando que con el encierro de las personas el contagio por el virus Covid-19 y la infraestructura sanitaria, puedan supuestamente tener mayor control, se observa en varias zonas del territorio nacional la exhibición de trapos rojos en casas, apartamentos, casuchas y remedos de viviendas, indicando que las familias que las habitan necesitan ayudas gubernamentales 0 , es de imaginar, de cualquier proveniencia para poder subsistir. Versiones encontradas dicen que surgió de una propuesta de gobierno en el municipio de Soacha, buscando que vecinos se ayudarán unos a otros, mientras que otra versión da cuenta que fue una propuesta ciudadana originada en el barrio Potosí, en la localidad de Ciudad Bolívar en Bogotá. Lo cierto es que rápidamente se propago a otras localidades y a otras ciudades.

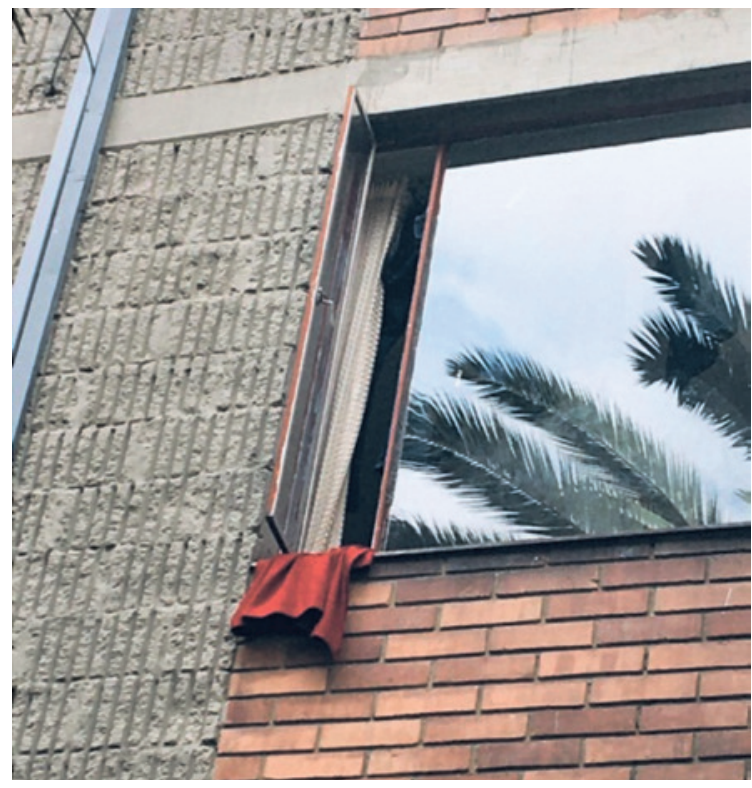

Imagen 1. Fotografía: Mariana Elorza Chávez. Bogotá, (abril 2020)
Paralelamente hemos visto que sectores de moradores en Bogotá, Medellín, Santa Marta, Santander, La Guajira y Sincelejo (EI Tiempo, 16 de abril de 2020) se han tomado calles de sus barrios para protestar por la falta de ayudas de los gobiernos central y regional. En Bogotá, habitantes de localidades como Ciudad Bolívar, Rafael Uribe, Suba, Usme, Bosa y Kennedy, han bloqueado vías y en algunos casos se han enfrentado con la policía que, como es costumbre, disuelve las manifestaciones con gases. De igual manera, se han escuchado los famosos cacerolazos en varias ciudades, en Cartagena apoyando a su alcalde por controversias con el Concejo Municipal y en otros lugares reclamando ayudas.

Este fenómeno ha convertido el trapo rojo en un símbolo de otra forma de protesta, tal como lo afirma un líder comunal de Usme, quién manifiesta que por la falta de ayudas "casi toda la localidad tiene trapos rojos en las ventanas de sus casas". (El Tiempo, 2020).

Es evidente que el trapo rojo y la cacerola son los símbolos que sirven hoy como instrumentos de comunicación en una clara aplicación de que lo iconográfico toma su papel de trasmisor, una característica del lenguaje, y que cada grupo social busca construir imágenes para expresarse.

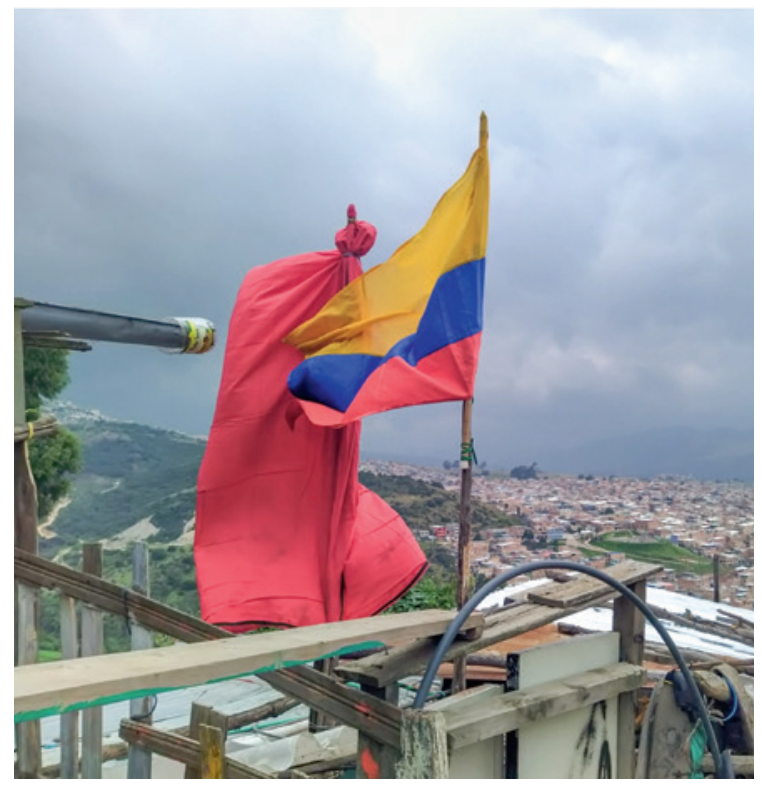

Imagen 2. Fotografía: Barrio Tocaimita, Localidad de Usme, Bogotá, Propiedad de Fundación Antífona. 


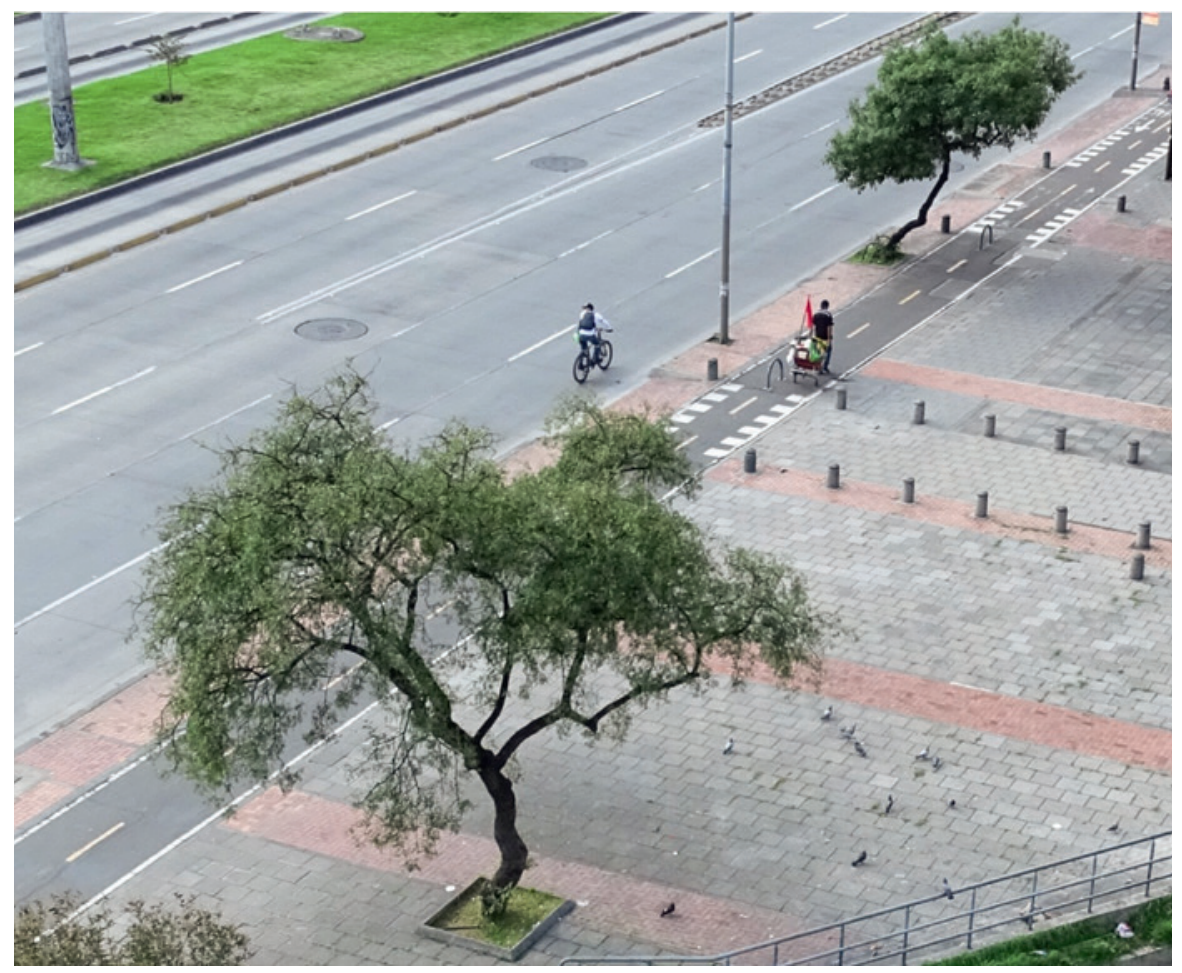

Imagen 3. Vendedor ambulante con bandera roja. Bogotá, (27 de abril de 2020).

Fotografía: Marcos González Pérez.

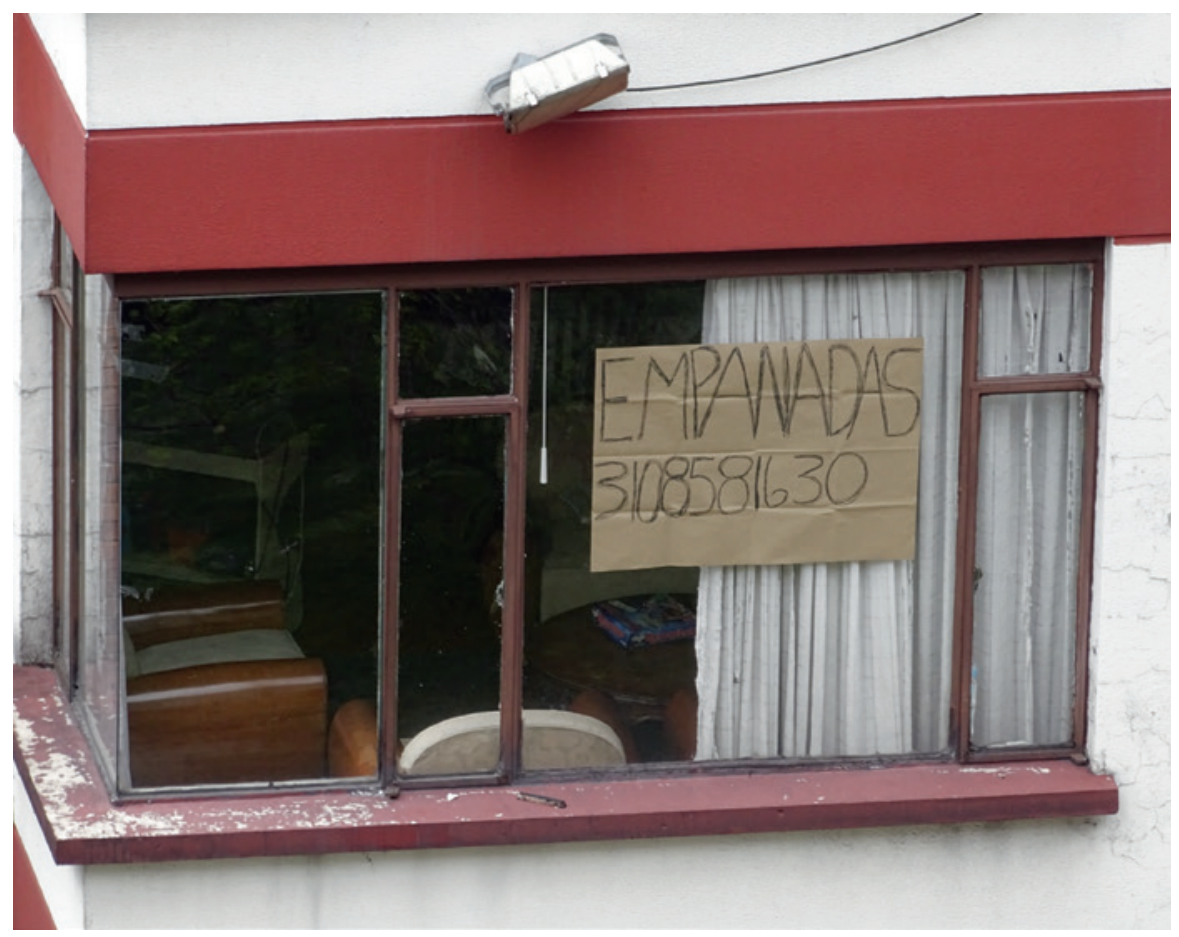

Imagen 4. Cartel de venta de empanadas en época de cuarentena. Bogotá, (23 de abril de 2020). Fotografía: Marcos González Pérez. 


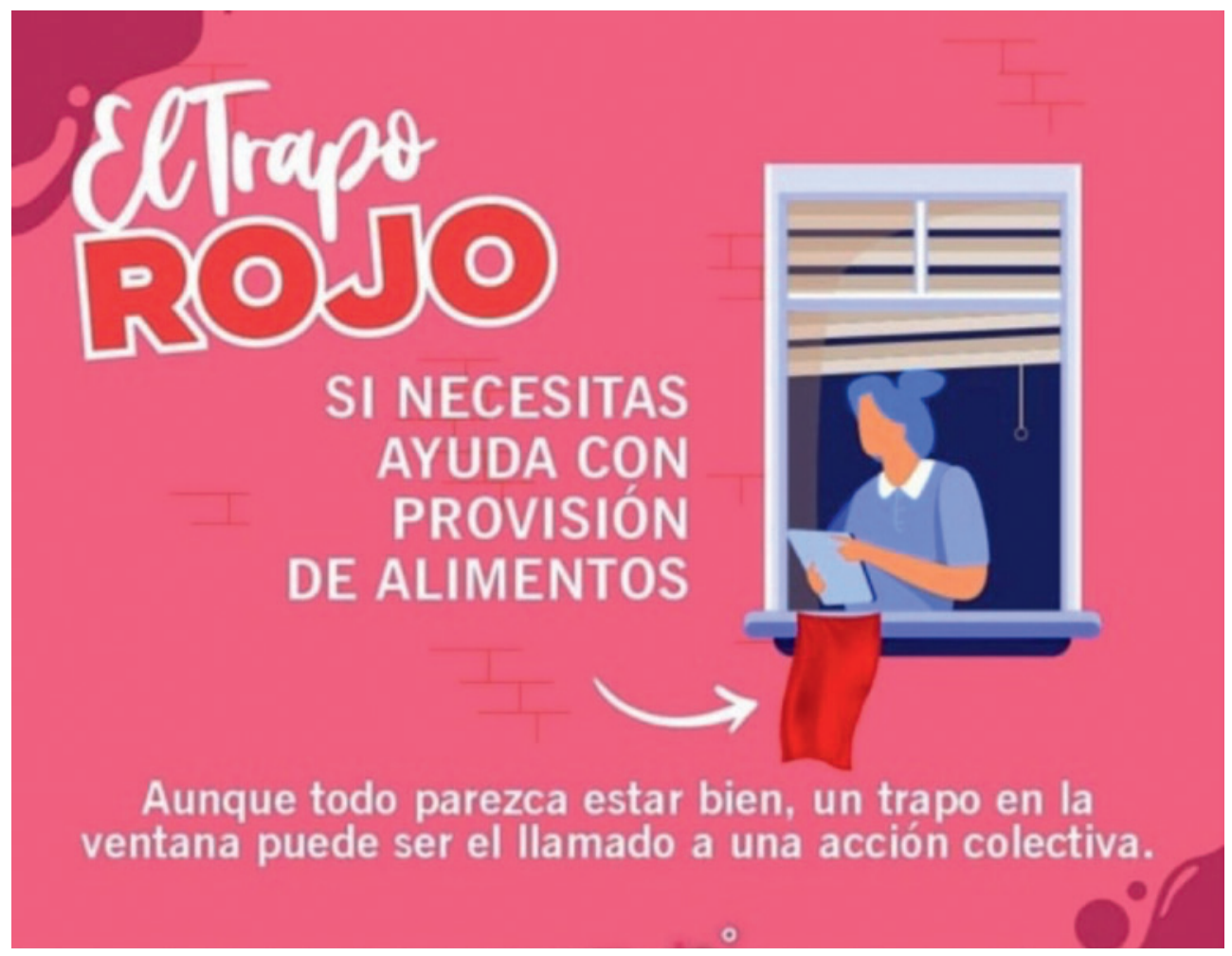

Imagen 5. El trapo Rojo (2020). Fuente: redes sociales.

Así pues, el trapo rojo no solo simboliza pedir ayuda sino que ha variado con la protesta y ya significa hambre.

El fenómeno ha logrado acciones impensadas. En una zona periférica de la ciudad de Medellín un grupo de pandilleros que dominan varios barrios buscaron un acuerdo con la policía para intercambiar armas por comida, con el fin de repartirlas entre los moradores de esas zonas. El hambre venció el terror. Y es que el problema tiene dimensiones mundiales. Según el Programa Mundial de Alimentos (PMA), de la Organización de las Naciones Unidas el impacto del covid-19 en la cantidad de personas en riesgo de morir de hambre en el planeta puede llegar este 2020 a afectar 265 millones de personas. Y la necesidad obliga a la invención de estrategias recursivas para obtener algún ingreso y poder comer, tal como lo observamos en la ventana de un edificio en Bogotá. $O$ en las calles por vendedores del rebusque.

Pero la bandera roja, trapo rojo, jirón rojo, tiene una historia.
1. De acuerdo con el historiador Bronislaw Baczko (1979, p. 15), la necesidad del movimiento obrero, en el siglo XIX, de buscar símbolos de representación orientó la búsqueda de una bandera que los identificara. Buscar un color propio, que los diferenciara de los Estados Nacionales, se hizo por parte de los obreros, según Baczko, a tientas y con dudas entre el rojo, el negro, los colores del arcoíris y el azul. Inicialmente, la bandera roja identificaba en Francia la instalación de un estado de emergencia contra los tumultos y la anarquía, pero con la decisión de los obreros de apropiarse de este color le dan un significado diferente. El simbolismo ahora tiene que ver ahora con el trapo empapado de la sangre derramada por los obreros en sus luchas y por lo tanto el rojo sirve de pregón. En Colombia la bandera roja del proletariado acompañaba, desde los años 20 del siglo XX, la conmemoración del Día Internacional de los Trabajadores $\circ 1^{\circ}$ de mayo.

2. En los años 20 del siglo XX, en Colombia, surge el Partido Socialista Revolucionario que contaba entre sus filas a la dirigente María Cano, elegida por los obreros de Medellín en 1925 como la Flor 


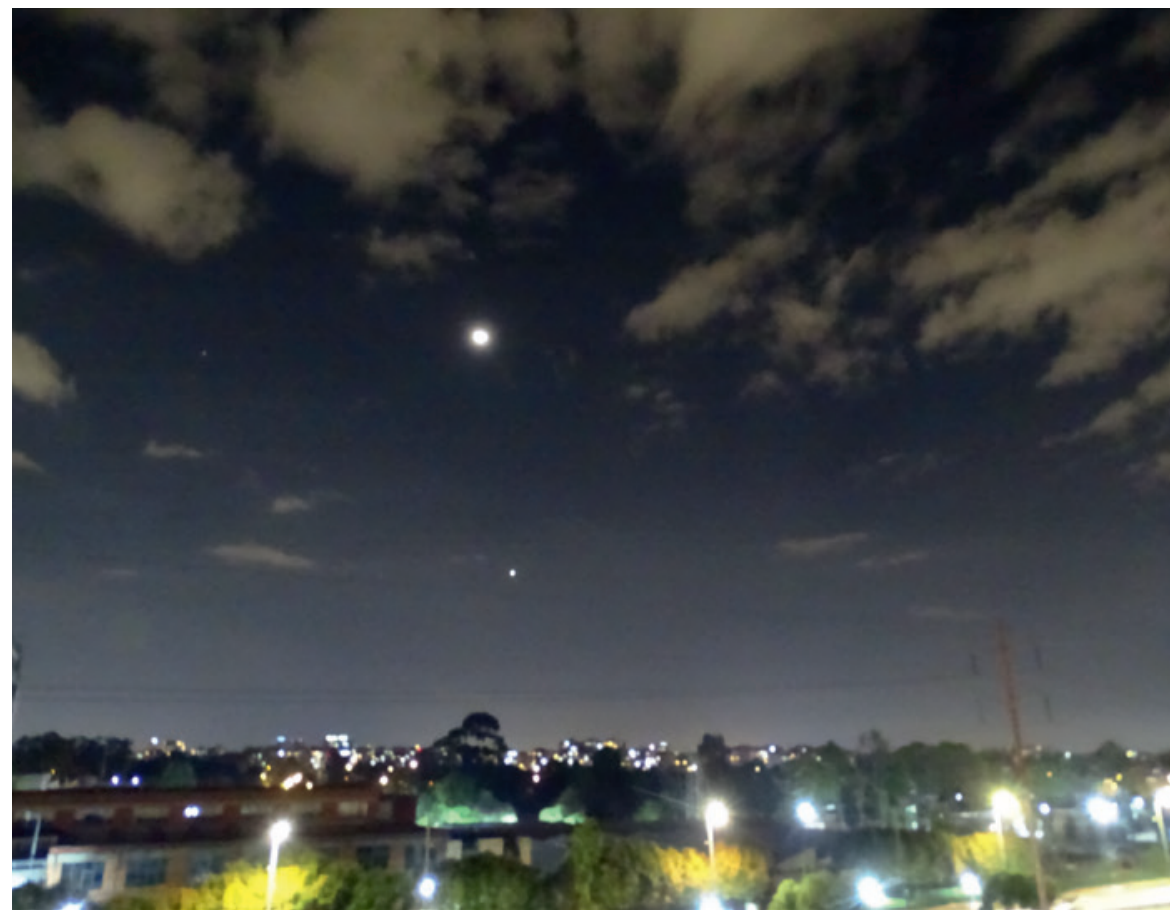

Imagen 6. La Luna y el Planeta Venus miran la cuarentena en Bogotá. Fotografía: Marcos González Pérez, (abril 2020).

Revolucionaria del Trabajo, quién ondeaba en sus proclamas la bandera roja como símbolo de las luchas sindicales. En el II Congreso Nacional Socialista realizado en 1920 , se acordó entre otros asuntos, que

La enseña del Partido Socialista será una bandera roja con un triángulo en el centro, hecho con el tricolor nacional. Dentro del triángulo los tres ochos bordados y las siguientes inscripciones: Estudio, Trabajo y Descanso, correspondientes a cada uno de los ochos. El rojo de la bandera es emblema de combate; el tricolor, patriotismo, y las inscripciones anteriores significan que el socialismo reconoce para los individuos, ocho horas para el estudio, ocho para el trabajo y ocho para el descanso. En los vértices del ángulo irá el lema del partido: Libertad, Igualdad y Fraternidad. (Periódico La Ola Roja, julio 23 de 1920)

En esos años impulsaron el ritual de prestar juramento a su bandera, "el jirón rojo, emblema de nuestra lucha" en el marco de lo que denominaba el "evangelio social" lo que provocó una fuerte disputa con los gobernantes nacionales quienes consideraban estos ritos como una profanación a la bandera tricolor, el emblema nacional. (González Pérez, 2019).
Después de la disolución del Partido Socialista aparece en los años 30 del siglo XX el Partido Comunista Colombiano que toma como emblema la bandera roja con el símbolo de una hoz y un martillo.

3.- En el año 2011, el Partido Liberal Colombiano, fundado en 1848, aprueba sus estatutos y en el Capítulo I, artículo 20, determina como su distintivo el color rojo "como interpretación del amor, la fraternidad y la tolerancia, y su emblema se acompañará con su símbolo que es la $L$ y el de la Internacional socialista, a la cual se encuentra afiliado". Estatutos Partido Liberal Colombiano).

4.- El trapo rojo también ha estado relacionado con otras esferas: en lo festivo, por ejemplo, el pañuelo rabo de gallo o rabuegallo (Abadía Morales, 2002, p. 39), que se usa en los trajes de los hombres que danzan el sanjuanero en las fiestas de San Juan y San Pedro en regiones de Tolima, Huila y Caquetá. El pañuelo de seda o satín rojo era parte de la vestimenta de campesinos de varias regiones y se usaba para proteger la parte posterior del cuello de los rayos del sol. 
En los deportes el rojo es distintivo de varios equipos profesionales de fútbol en Colombia y han popularizado el grito: "dale rojo dale".

Varios movimientos políticos surgidos en el siglo XX han tomado esta bandera roja y le agregan un distintivo especial para identificarse con sus ideologías de origen, como es el caso del Partido Comunista con la hoz y el martillo de tendencia soviética, o el Moir con su bandera roja y una estrella amarilla, de tendencia maoísta.

A nivel mundial también varios partidos socialistas utilizan el color rojo en sus banderas o en sus logos, como España y Francia.

Las carnicerías o famas, como se les llama comúnmente identifican su lugar como espacio de venta de carne, inicialmente, de vacunos, con un trapo rojo. La fama era una de las carnicerías más importantes de Bogotá en el siglo XIX, de ahí que este nombre se propagara para este tipo de lugar comercial.

Así pues, el trapo rojo ha estado ligado a la historia de la nación colombiana por sus múltiples significados, y hoy puede resurgir como el emblema de los reclamos sociales, toda vez que ya en las protestas callejeras, en algunos barrios, están agitando el chiro rojo bajo la consigna: "Mejor morirnos de coronavirus que de hambre".

\section{II}

\section{Faro de colores}

\author{
Menos mal existen el arte, la música, la literatura y la poesía. \\ Acuérdense que Churchill declaró el labial rojo artículo de \\ primera necesidad: \\ para ayudar a subir el ánimo..." \\ (Vanessa de la Torre, periodista. \\ En Publimetro, 21 de abril de 2020)
}

Mientras la Luna y Venus se juntan en el infinito y parecen mirar la cuarentena en Bogotá, empieza a emerger en Colombia un faro de colores bien significativo: el púrpura o el negro como distintivo de violencia intrafamiliar, especialmente por la violencia contras las mujeres, en esta época de cuarentena, que ha obligado a las autoridades a abrir una línea de teléfono especial para denunciar estos horrores, denominada justamente línea púrpura. Y el color negro, en el mismo sentido y ya difundido en las redes sociales.

Un trapo negro es indicativo de que en el lugar donde se coloca hay violencia de género, también

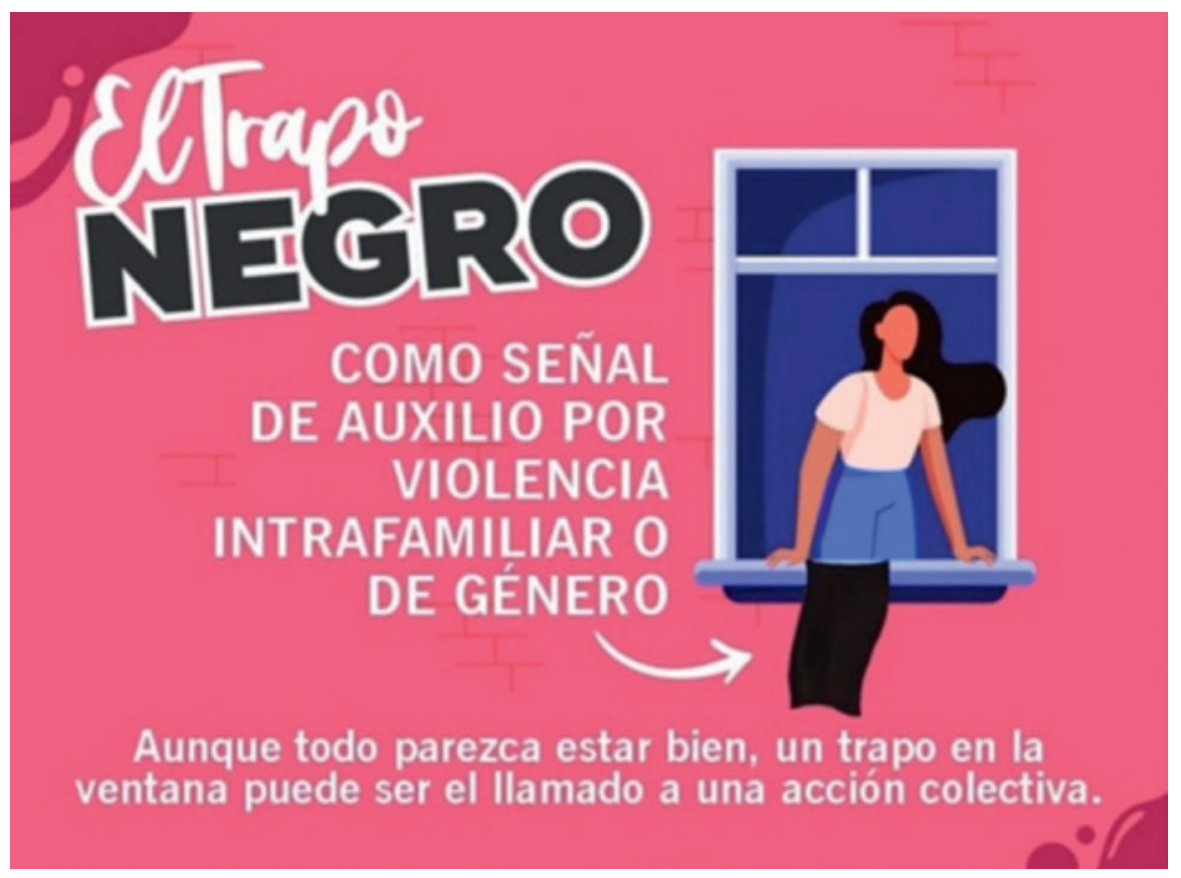

Imagen 7. El trapo Negro (2020). Fuente: redes sociales. 


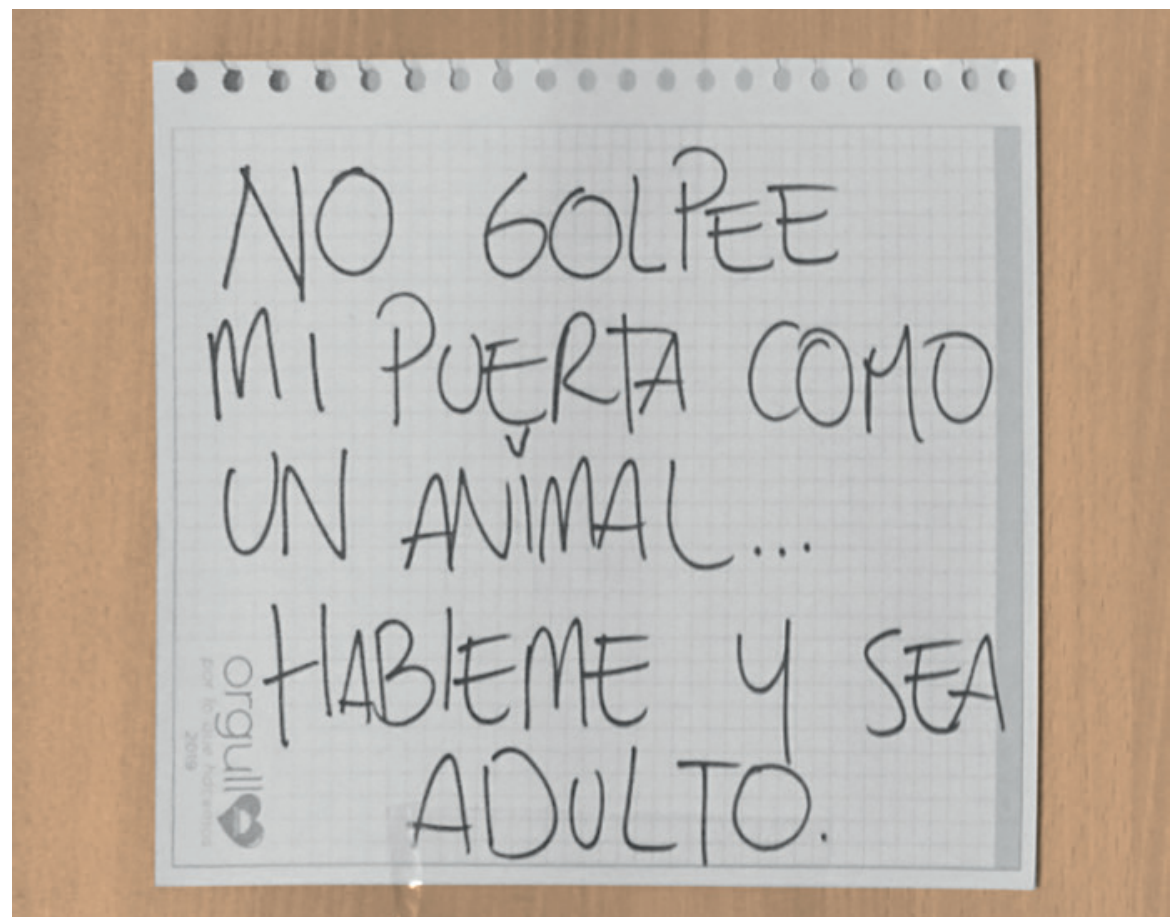

Imagen 8. Cartel colocado en la puerta de un apartamento en Bogotá por una joven violentada por un vecino debido al ruido que hacía al hacer ejercicio. Fotografía: Marcos González Pérez, (abril 24 de 2020).

algunas mujeres dejan ver en sus cuellos una cinta o cordón de color negro, como pidiendo auxilio. El Instituto Nacional de Medicina Legal y Ciencias Forenses reveló que entre los meses de enero y marzo de 2020, se registraron en el país 15.440 hechos de violencia intrafamiliar en Colombia lo que ha propiciado que se creen varios canales de atención. Algunos centros de comercio y droguerías habilitaron un programa denominado "En casa sin violencias" donde las mujeres pueden llegar para informar de violencias caseras y estos informan de inmediato a la policía. Es una estrategia tomada de España donde se denomina "mascarilla 19". (El Tiempo, 21 de abril de 2020). Allí cuando una mujer es violentada, pide una mascarilla19 y se activa el protocolo de alerta para buscar protegerla. Estos datos hacen parte de las altas cifras de actos de violencia originados por intolerancias, pese a los llamados a la solidaridad y a la paciencia en esta época de cuarentena.

El azul, como distintivo para saber que en determinado lugar hay problemas de salud. Ya utilizado bajo el slogan: manos pintadas de azul, por una empresa prestadora de salud como parte de una campaña en favor de personas en riesgos vulnerables y sin protección en salud.

Debería ser el color de las protestas de los trabajadores de la salud que tienen que manifestarse por el derecho a la vida, a que no sean amenazados de muerte por cumplir con su labor y a que los doten de elementos de protección apropiados para sus labores, así como a que no los maltraten por ser considerados portadores del virus. Llevan varios muertos en su gremio y sectores de la población rechazan su cercanía en un acto máximo de intolerancia. Irónicamente, resultaron victimarios y no víctimas, como es su realidad cotidiana. No obstante un sector de la población aplaude su existencia y coraje y apoya sus justas protestas y ya se propago la idea de considerarlos "ángeles de la salud". Desde mediados de abril, cada día, a las 8 p.m., cientos de personas salen a las ventanas o a las puertas de sus casas y aplauden, con o sin presencia de ellos, a médicos, enfermeras y a todos los que contribuyen con su labor a salvar vidas. (Fernando Quiroz, El Tiempo, 28 de abril de 2020). 


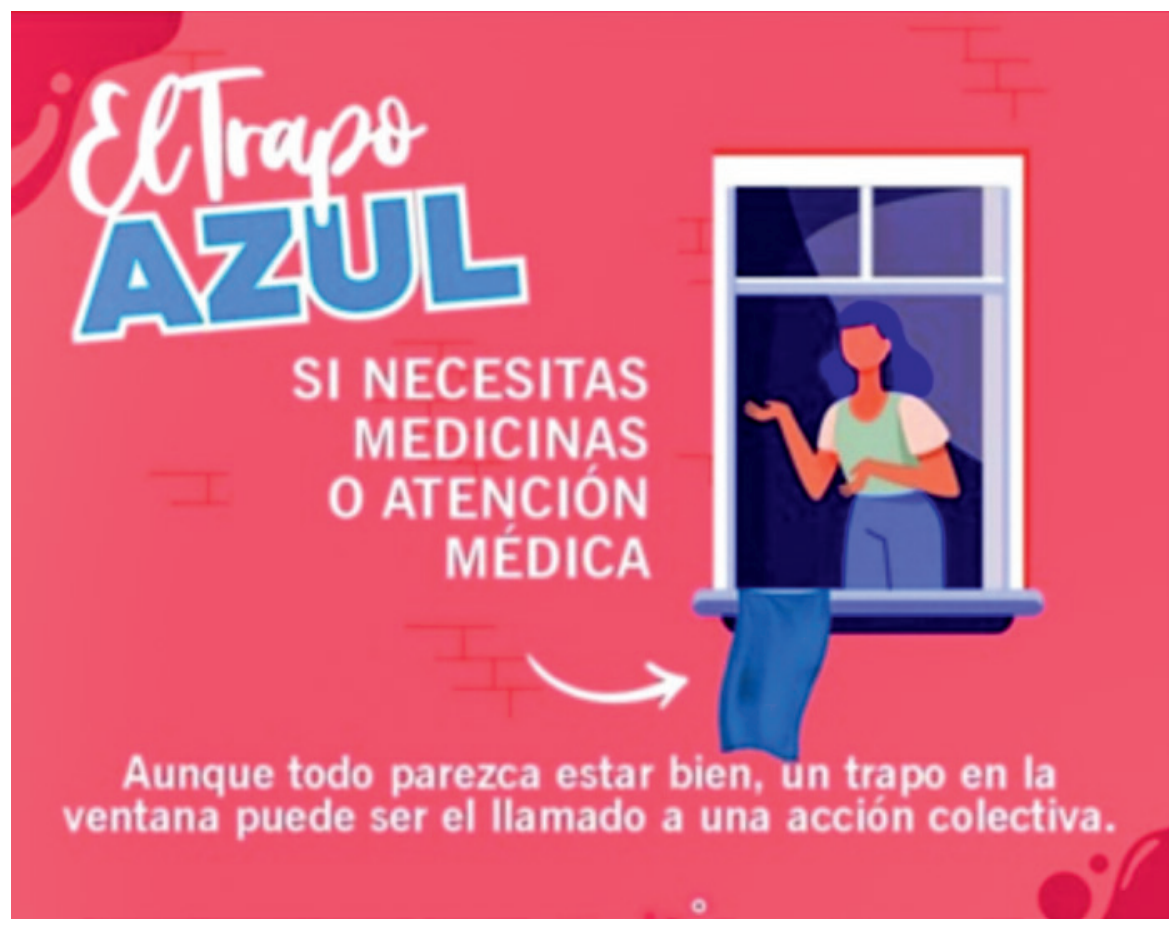

Imagen 9. El trapo Azul (2020). Fuente: redes sociales.

A estos sucesos se suma el insólito caso de los asesinatos de líderes sociales en Colombia. "En el sistema de información de la organización Somos Defensores se registraron 62 homicidios contra líderes sociales en todo el país en el primer trimestre del año" se lee en El Espectador del 9 de abril de 2020, justo el Día Nacional de la Memoria y la Solidaridad con las Víctimas del Conflicto Armado, que se conmemora oficialmente desde el año 2012.

En Italia, se observan niños en las ventanas con banderitas arcoíris, significando esperanza, un imaginario social que ha traspasado todas las fronteras.

Así pues, el crisol de colores se direcciona socialmente para identificar situaciones propias de la crisis creada por el virus que ataca la humanidad en este siglo XXI, que con esta catástrofe pareciera marcar su conteo como año Uno, dado que puede crear una ruptura de tiempo signada por otras formas de relación con la naturaleza, con el otro y consigo mismo. Vale la pena recordar a Eric Hobsbawm, el historiador, quién afirmaba respecto del siglo $\mathrm{XX}$.
La infinita variedad de la especie humana y la rapidez con la que han cambiado en el transcurso del siglo XX hacen verdaderamente difícil elegir un símbolo de la gente corriente. $Y$, sin embargo, repito, si me veo en la necesidad de elegir uno escojo a una madre con sus hijos. (2000, p. 212)

Con el criterio de considerar que los adultos mayores son "desechables", ya hace lejanos tiempos determinada por el sistema financiero y las compañías de seguros para los mayores de 70 años, detestados como estorbos para la vida de los demás, en el marco de la pandemia que nos azota, el símbolo humano que sobresale, por lo menos en los albores de este siglo XXI, sería una foto contra El Olvido. Aunque según José Saramago (2015): "sabremos cada vez menos qué es un ser humano."

\section{III}

\section{La fiesta}

¿Y la fiesta? Los elementos que se han puesto en escena en esta maraña de incertidumbres han permitido que uno de los pilares de lo festivo, el color, sea un protagonista. Este, en lo festivo, hace 


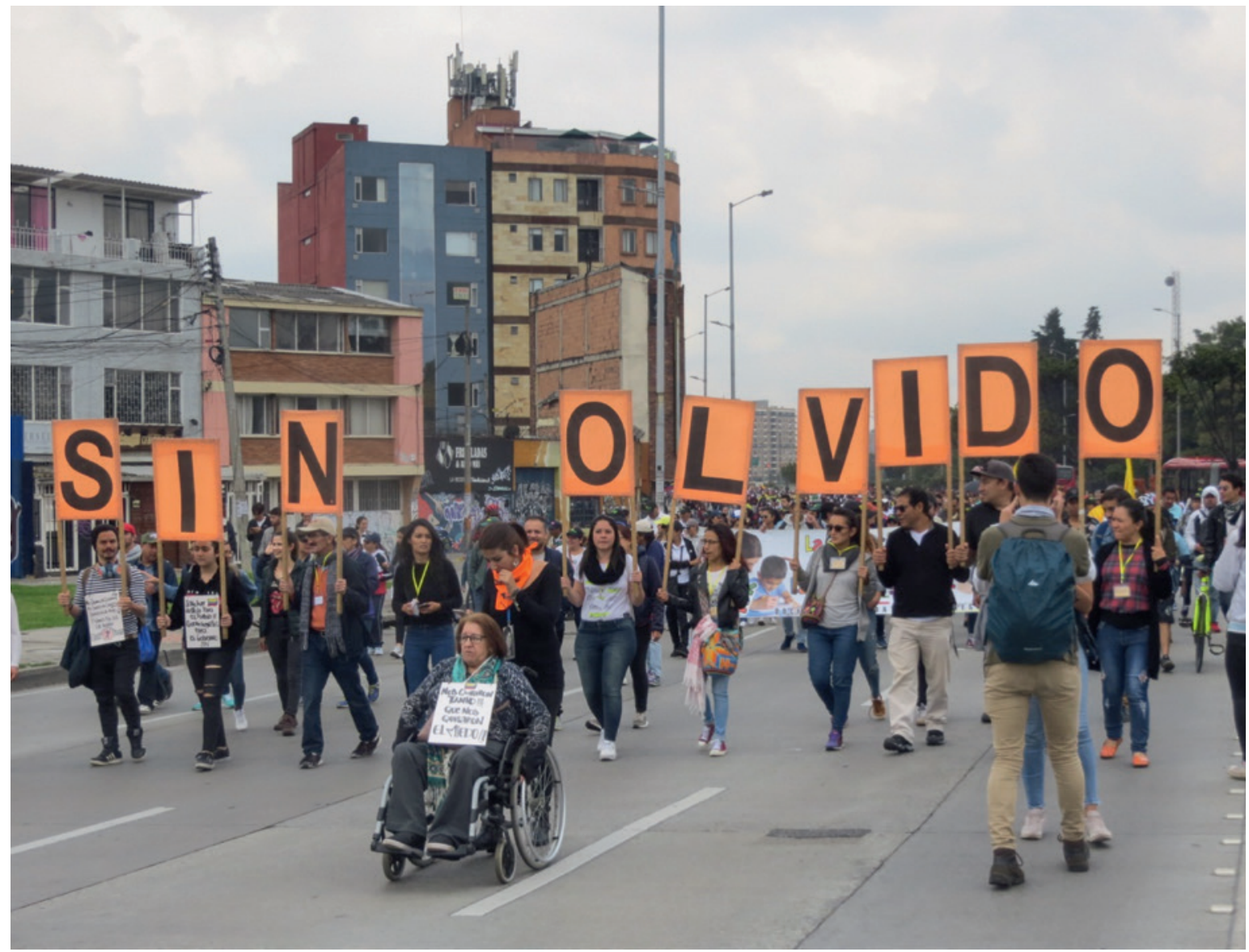

Imagen 10. Señora adulta encabeza una marcha contra El Olvido en un acto de Memoria en Bogotá.

Fotografía: Marcos González Pérez, Bogotá, (noviembre, 2019)

conjunto con los sabores, los olores, las escenografías, las músicas, los cantos, entre otros. Así mismo el calendario de lo festivo orienta formas de comportamiento de individuos y comunidades y en muchas regiones el tiempo se mide por la fecha de la fiesta. Antes o después del carnaval, es una actitud que rompe el tiempo de lo cotidiano. Por eso el tema es de suma importancia en un país como Colombia, para solo dar un ejemplo, donde se escenifican cada año alrededor de 4000 fiestas.

Después de carnavales (febrero 2020) llegaron las noticias de confinamiento y por supuesto la suspensión de actividades de masas. La alcaldesa de Bogotá lanzó una especie de orden: festivos sí, pero no para vacaciones, referido a los llamados puentes festivos (sábado, domingo y lunes) que existen en el calendario colombiano. Y para darle mayor control cerraron las fronteras territoriales para impedir la movilidad. Así, esta es una de las tantas consecuencias de la cuarentena. Teniendo en cuenta que uno de los descriptores de la fiesta es la diversión, al lado de la celebración, la conmemoración, el festejo o el recordar, pues se interfiere, por obvias razones de sobrevivencia, parte de la esencia de lo festivo.

Pero la fiesta no se detiene. Puede variar su forma de manifestación y es eso lo que se observa desde el mes de marzo.

Es el caso de algunos rituales. Uno de los más conocidos como el lumbalú, rito ancestral de origen africano, que reúne a las comunidades alrededor de cantos y bailes al son de tambores y rondas para despedir a sus muertos, no se escenifica para evitar contactos personales que puedan originar contagios de coronavirus, no obstante que a la fecha (23 de abril) no se ha presentado 
ningún caso en esta zona cerca de Cartagena. Allí, en San Basilio de Palenque, en el departamento de Bolívar, lugar emblemático de los residentes de origen africano, "nos toca elevar nuestras plegarias a los orishas (divinidades) de forma individual en las casas buscando protegernos" dice Manuel Pérez, un gestor cultural de Palenque. (El Tiempo, 23 de abril de 2020).

El 9 de abril se conmemora el Día Nacional de la Memoria y la Solidaridad con las Víctimas del Conflicto Armado, establecido mediante la Ley de víctimas del 2011, artículo 142.

En el año 2020 coincidió la fecha con el jueves santo y con la pandemia Covid-19, de tal manera que no se realizaron, por obvias razones, actos públicos. Las organizaciones de víctimas lanzaron la propuesta de realizar una velatón el jueves 9 de abril a las 8.p.m., desde las casas en memoria a los 9 millones de personas que han sido víctimas del conflicto armado en Colombia.

Días antes, en una publicación de prensa (Justicia. El Tiempo) se leía:

El Centro Nacional de Memoria Histórica, está impulsando el hashtag \#9AUnaSolaVoz y un micrositio desde el Museo Nacional de Memoria en el que se establece una agenda virtual para esta semana en la que se preguntan por los hechos del asesinato de Gaitán y por cómo podemos ser solidarios con las víctimas. (...). Otro componente de esta celebración, pese a la virtualidad, correrá por cuenta del Sistema Integral de Verdad, Justicia, Reparación y No Repetición, del cual hacen parte la Jurisdicción Especial para la Paz (JEP), la Comisión para el Esclarecimiento de la Verdad y la Unidad de Búsqueda de Personas dadas por Desaparecidas.

Dos entidades distintas que en una especie de encuentro/enfrentamiento conmemoran el mismo objeto, pero desde miradas diferentes.

En relación con los festivos de convocatoria nacional se iniciaron con los días de Semana Santa, los cuales hacen parte del calendario católico. Los rituales, sin acompañamiento de gente, fueron trasmitidos por la televisión, y en casos más puntuales algunos curas recordaron la muerte y resurrección de Jesucristo ante las fotografías de los fieles de su parroquia. Otros siguieron las ceremonias a través de la radio. Puede afirmarse que, por ahora, los rituales se mantienen, no varían. Permanecen, se dice en los estudios de lo festivo. Las procesiones más tradicionales y suntuosas como las de Popayán y Mompox se suspendieron. El Festival Nacional del Burro, realizado cada año en el mes de abril en San Antero (Córdoba) es un encuentro festivo muy concurrido donde se aprecia la utilidad del burro en el acompañamiento al trabajo campesino. Se programan concursos y hay también muestras de la cultura cordobesa. Siguiendo las directrices del gobierno nacional el evento se aplazó para otra fecha sin definir todavía.

Para el 23 de abril, Día del Libro y del Idioma, que tiene como una de sus actividades de encuentro la Feria Internacional del libro de Bogotá, evento muy concurrido, la situación obligó a organizar un encuentro virtual. Conferencias, lanzamiento de libros y otras actividades propias para estos casos, pasan este 2020 a ser parte de la programación virtual. En instituciones educativas se realizan conferencias, concursos de poesía y dibujo, pero virtuales y el comercio promociona descuentos en libros como parte de la celebración. Un dato curioso. Algunas cadenas de droguerías lanzaron la celebración del Día Internacional del Libro y no mencionando que es el del Idioma, con una promoción de sus libros de salud, dietas y bienestar con descuentos del $20 \%$. Lo que se detecto es la ausencia de mención al verdadero origen de esta fiesta: el Día del Idioma Castellano, en homenaje a Miguel de Cervantes Saavedra, fallecido un 23 de abril de 1616, autor de Don Quijote de La Mancha.

Para finales de abril de cada año se programa el Festival de la Leyenda Vallenata en la ciudad de Valledupar (Cesar), encuentro bastante concurrido por artistas y un público internacional numeroso. Realizado durante una semana plena de concursos musicales cuyo eje es el vallenato y el acordeón, el encuentro tiene también actividades como muestras gastronómicas, desfiles de pilanderas, lugares para bailar y la gran tarima donde se presentan los principales cantantes y conjuntos de la música de este género.

En el año 2020 la variación por la pandemia lo ha llevado a organizar un programa virtual nominado Fesvallenato Live emitido cada día en horas vespertinas para que los aficionados "vivan" este festejo del folclor. Así pues, no se suspende el 


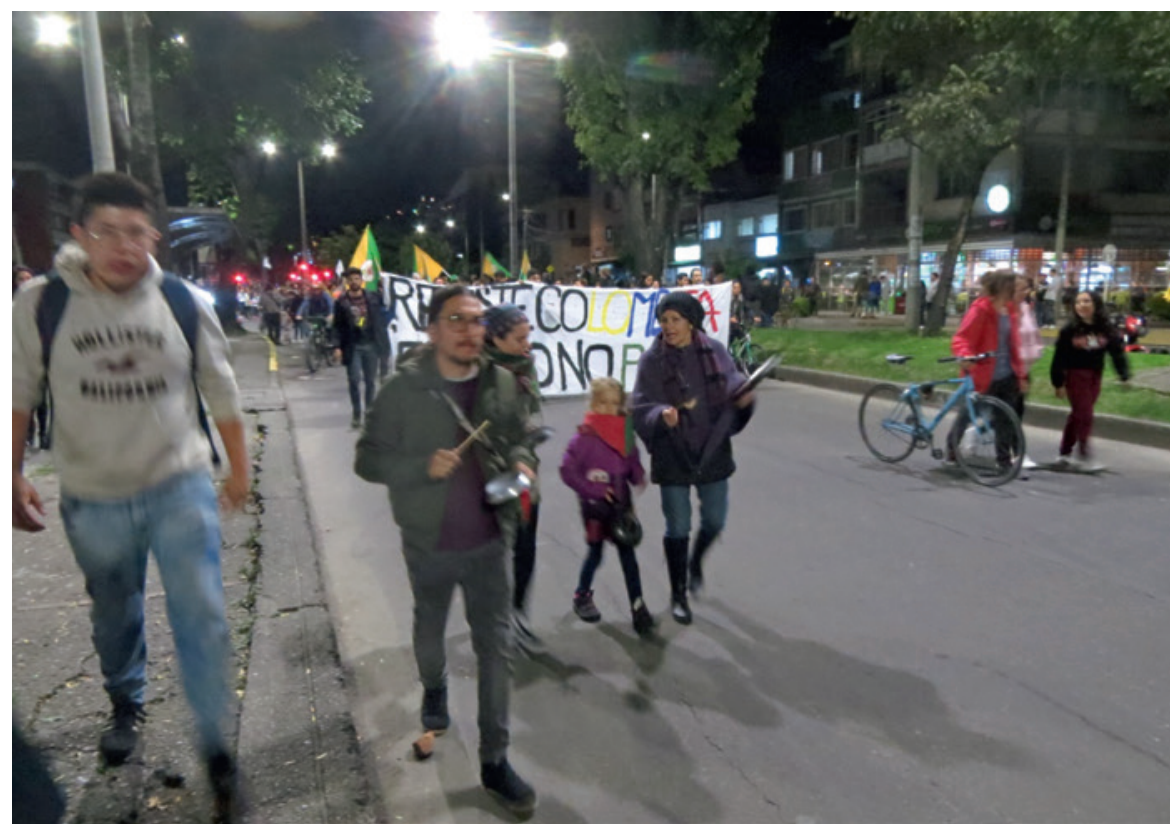

Imagen 11. Paro Nacional, Bogotá (noviembre, 2019). Fotografía: Marcos González Pérez.

encuentro buscando preservar este encuentro considerado Patrimonio Cultural Inmaterial de la Humanidad.

El 29 de abril se celebra el Día Internacional de la Danza, evento que ha tomado mucha fuerza en el mundo y en Colombia. Generalmente se programan funciones de danza en varios escenarios de la ciudad con asistencia masiva, así como encuentros académicos de gran importancia. Creado por la Unesco en 1982, en homenaje al natalicio del bailarín y coreógrafo francés Jean-Georges Noverre, ya hace parte en Colombia de los nuevos días de festejo. También varió su forma de celebración, en las redes se encuentran múltiples puestas en escena y lo mejor es la invitación que se hace para este día: bailar.

El Primero de Mayo, Día Internacional de los Trabajadores, que cae en puente festivo (2020) no pudo ser vivido como fecha de diversión por quién no lo conmemora, ni tampoco aprovechado para las acostumbradas marchas callejeras de protesta por los celebrantes, no obstante, en muchas partes se proclama que se tiene más miedo al hambre que al coronavirus. Sin embargo, salvo algunos mensajes virtuales recordando la fecha, este 10 de mayo 2020 ha sido seguramente el día más lúgubre para los trabajadores. Para un sector como el de la cultura las noticias de prensa son catastróficas: “El sector de la cultura perdió más de 500.000 empleos en marzo" titula en primera página un periódico (EI Tiempo, 10 de mayo de 2020) y la tasa de desempleo subió a 12,6\% considerada la más alta en la última década. Unas condiciones económicas propicias para hacer público este desastre laboral en un día como el de los trabajadores, fecha en que se conmemora la masacre de varios obreros en la ciudad de Chicago en 1886 por reclamar la jornada de 8 horas de trabajo. Esta fecha tiene su historia:

La feliz idea de instaurar un día de fiesta proletaria para lograr la jornada laboral de ocho horas nació en Australia, donde ya en 1856 los obreros habían decidido organizar un día completo de huelga, con mítines y entretenimiento, como una manifestación a favor de la jornada de ocho horas. Se eligió el 21 de abril para esa celebración. Al principio los obreros australianos pensaban en una única celebración, aquel 21 de abril de 1856. Pero como esa primera celebración tuvo un efecto muy fuerte sobre las masas proletarias de Australia, animándolas con ideas agitadoras, se decidió repetirla todos los años. Efectivamente, ¿Qué podría proporcionarles a los trabajadores más coraje y fe en su propia fuerza que un paro masivo, decidido por ellos mismos? ¿Qué podría proporcionarles más valor a los eternos esclavos de las fábricas y de los talleres que el reconocimiento de su propia gente? Por eso, la idea de una fiesta proletaria fue 
rápidamente aceptada y comenzó a extenderse de Australia a otros países, hasta conquistar finalmente todo el mundo proletario. Los primeros en seguir el ejemplo de los obreros australianos fueron los norteamericanos. En 1886 se fijó el 10 de mayo como el día de la huelga universal. Ese día, 200.000 trabajadores abandonaron sus lugares de trabajo y exigieron la jornada laboral de ocho horas. Más tarde, la policía y el hostigamiento legal impidieron por muchos años la repetición de esa gran manifestación. Sin embargo, en 1888 restablecieron su decisión y fijaron el 10 de mayo de 1890 como el día de la siguiente celebración. ${ }^{1}$

En Colombia tenemos referencia de su realización desde el año 1914. (González Pérez, M., 2020). En este 2020 en Colombia la conmemoración pasó prácticamente sin ser recordada. Sin unas orientaciones de los líderes promoviendo, como en algunos países, cacerolazos en puertas y ventanas en horas definidas o exhibición de pancartas en las ventanas con las demandas sociales o agitación de chiros, bufandas o trapos rojos, fueron más bien los grandes ausentes. Las multitudinarias concentraciones y marchas de otras épocas, agitando reivindicaciones sociales, quedaron suspendidas por la pandemia, pero la ausencia de estrategias para utilizar las rutas virtuales y cohesionar la protesta ciudadana dieron paso, sin duda, a la nostalgia por la cacerola.

La Cruz de mayo, el 3 de mayo, una fecha de carácter religioso que por lo menos en Bogotá convoca muchas personas en los templos católicos para bendecir una cruz fabricada en madera o en laurel de cera o en hojas de maíz. También en varios lugares se construyen altares con la cruz cubierta de flores y frutos. Tiene varios significados, pero en general es implorar a Dios por protección en todos los campos. También ha generado polémicas por el uso del laurel de cera que afecta la naturaleza.

El ritual de la bendición de la cruz en 2020 se hará vía virtual y parece que los trapos viejos servirán de material para la fabricación de la cruz dado el confinamiento social. Algunos creen que por el significado de demanda de protección divina este 3 de mayo acrecentará el número de fieles, implorando desde sus moradas.

1 Ver [en línea] «www.laizquierdadiario.mx»
La fiesta del Día de la Madre, (segundo domingo de mayo), entre otros, uno de los días de mayor violencia intrafamiliar, será trasladada para un día de agosto o septiembre, según piden los grandes beneficiados, los comerciantes, agrupados en la Federación Nacional de Comerciantes, (Fenalco), quienes consideran que debe haber una reapertura gradual de la economía y por lo tanto este festejo no puede ser suspendido, sino trasladada su fecha de realización. Su origen oficial data de 1923 cuando Elvira Zea Hernández, reina de los estudiantes, elegida en el marco de los carnavales estudiantiles de los años 20 del siglo XX, que organizaba la Universidad Nacional, propuso al gobierno central que se aprobará en Colombia el festejo del Día de la Madre. El antecedente en Colombia también se encuentra en los programas de los carnavales estudiantiles de esos años, dado que el último día de la programación tenía como una de sus actividades el homenaje a las madres de los estudiantes. En 1925 se promulga la Ley 28 firmada por el Presidente de la República Pedro Nel Ospina, mediante la cual se decreta la creación de la "fiesta nacional de la bandera nacional" y se designa el 7 de agosto como fecha de su celebración. En la misma Ley se creó la fiesta del día de las madres, convertida así en una fiesta nacional y se determinó que se realizaría cada segundo domingo de mayo. (Artículo 40 de esa Ley). (González Pérez, M., 2019).

En mayo 25 se realiza la fiesta religiosa de la Ascensión del Señor, cuya tradición es la celebración de oficios religiosos, los cuales seguramente serán oficiados sin público.

Viene junio con sus fiestas calendario de Corpus Christi, Sagrado Corazón de Jesús y San Pedro y San Juan. La primera de ellas se celebra en algunas regiones de Colombia donde las danzas, cucambas y diablos son los símbolos principales de la celebración. Es posible que para la época se organicen actos públicos, toda vez que en algunos lugares se escenifica el día del campesino con sus desfiles de carrozas plenas de frutas. En otros lugares como Valledupar, donde es reconocida la tradición de los diablos danzantes (Jairo Soto, 2017) o en el Corpus Christi celebrado por la comunidad Kankuamo de la Sierra Nevada de Santa Marta, cuya gran tradición son los pagamentos, 


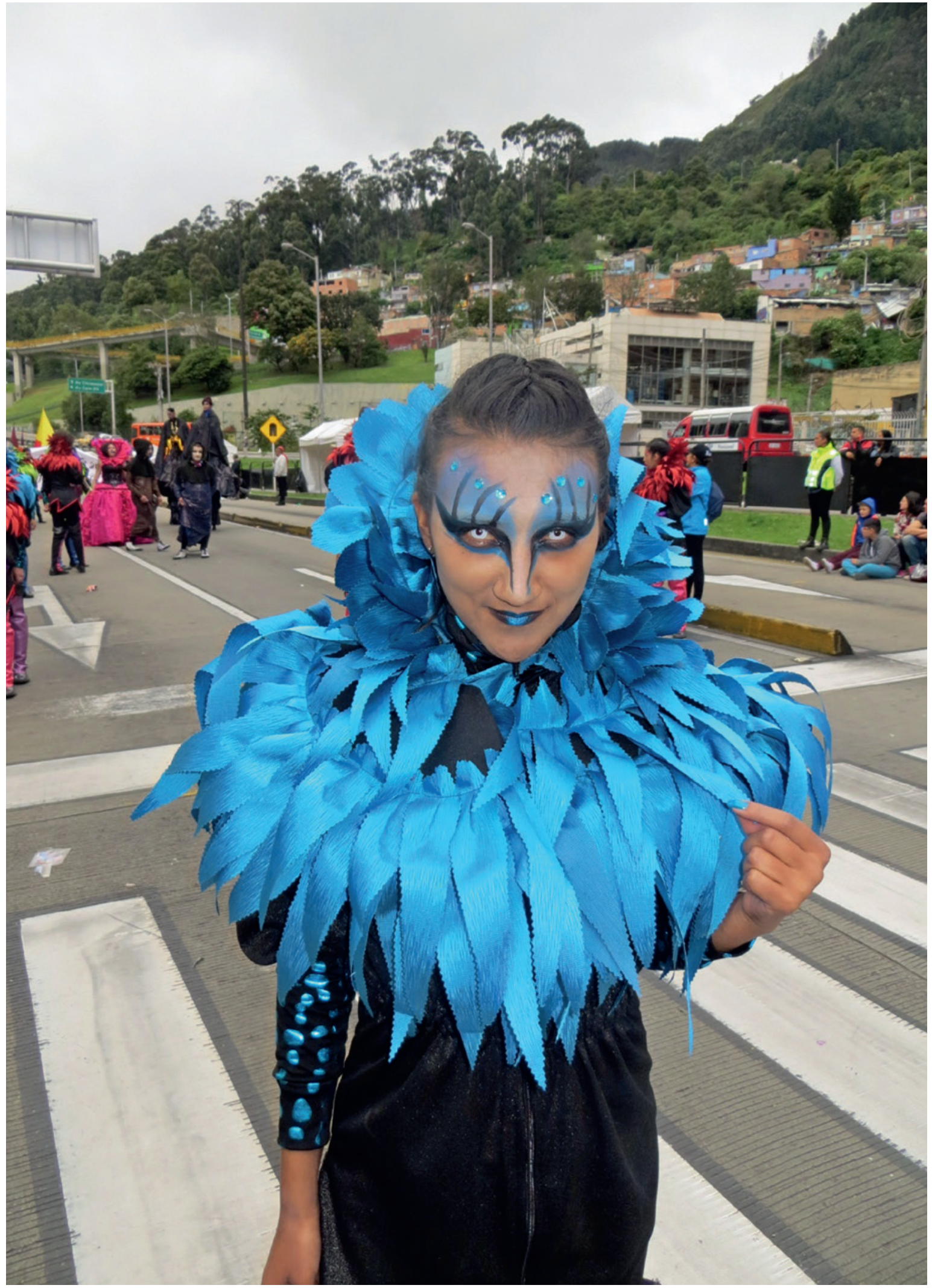

Imagen 12. Comparsera, en desfile de comparsas, Bogotá, (12 de junio de 2018). Fotografía: Marcos González Pérez. 


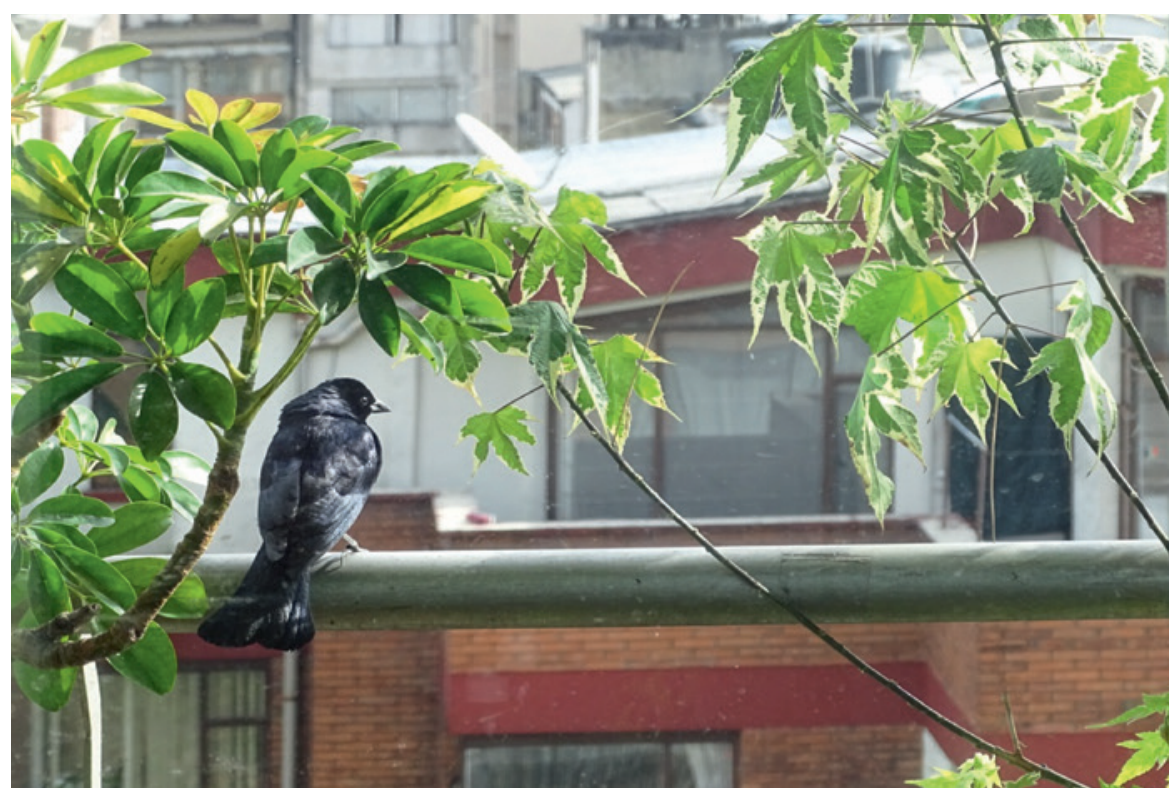

Imagen 13. Fotografía: Marcos González Pérez, Bogotá (abril, 2020). Especie Tordo Llanero.

seguramente serán puestos en escena por las respectivas comunidades.

Aparece también en este mes la fiesta del Sagrado Corazón la cual es más una celebración de devoción religiosa de los católicos que por costumbre se hace al interior de los templos.

La que si espera por definiciones precisas es la Fiesta de San Juan y San Pedro calendada para finales de junio, principalmente en regiones de Huila y Tolima donde los festejos combinan ciertas actividades religiosas con la realización de los modernos festivales donde los reinados, muestras culturales, bailes y goces son actividades que se escenifican durante varios días. Es el primer acto festivo de gran concurrencia local, nacional e internacional que permitirá observar si se retorna a la normalidad festiva o si la pandemia trastorno estas costumbres. Un gran laboratorio de la vida.

Lo que si puede suceder es que los recursos del Estado, que generalmente sirven de algún apoyo para la programación, no sean suministrados aduciendo que los gastos durante la pandemia son los prioritarios. La empresa privada, principalmente la de licores, puede aparecer apoyando financieramente los espectáculos de masas dado que hace parte de sus estrategias financieras, lo que supone además una interferencia fuerte para que el espectáculo prime sobre los actos culturales. Enorme reto para los vigías del patrimonio.

También estarían en espera festejos grandes como el Festival de Música Andina Colombiana que se realiza en Ginebra (Valle), generalmente en junio; el Festival Internacional del Joropo en Villavicencio, a finales de junio y La Fiesta Nacional del Café, que se celebra a finales de junio, entre otras grandes fiestas de gran concurrencia.

El Festival Iberoamericano de Teatro 2020, la fiesta de teatro más importante de Colombia, programada cada dos años, según sus organizadores se realizará del 19 de junio al 5 de julio de 2020. Sin embargo la primera actividad propuesta para el mes de abril, un desfile de comparsas y la presentación de algunas obras, fue suspendida. El festival que intenta sobrevivir a problemas internos y a un fuerte déficit financiero sueña con logar poner en escena toda su programación. Pero los grupos de teatro de otras naciones programan su participación con varios meses de anticipación lo que por las inciertas circunstancias incidirá en la calidad del evento, si se realiza. Sin duda, el lema de su creación: Un acto de fe en Colombia es su gran imaginario. 


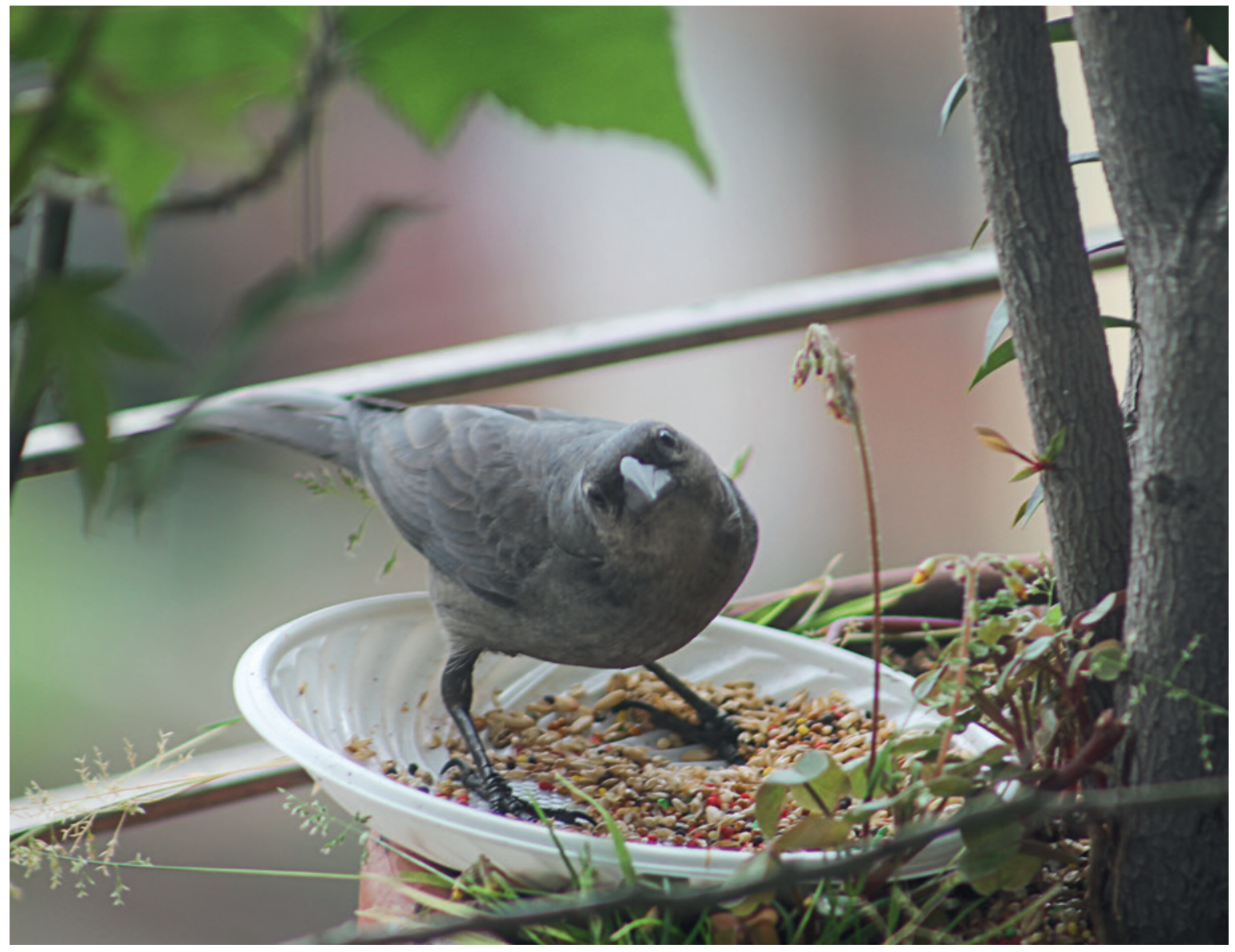

Imagen 14. Fotografía: Marco Daniel González Santoro, Bogotá (abril 2020).

Especie Tordo Llanero (hembra).

En julio, la conmemoración del día de la independencia, el 20 de julio, puede significar que no se realicé el acostumbrado desfile militar en Bogotá. En general es un festejo sin mucha apropiación social, pero como esta calendado un lunes podría significar que teniendo tres días de asueto nacional se convierta en la primera gran movilidad turística en Colombia: playas, piscinas, bailaderos, ríos, represas, quebradas, parques temáticos, serán vividos como espacios para el desahogo del encierro de la cuarentena. Un desafío enorme para el resto del año y de pronto de la vida.

Los meses que siguen, de acuerdo con el calendario, plenos de festejos regionales de todo tipo, esperan, bajo una expectante incertidumbre, mejores ambientes para sus puestas en escena. Muchos de esos encuentros festivos, entre otros el acostumbrado desfile de comparsas en Bogotá, que se realiza en agosto, dependen de recursos públicos para su ejecución y tal como se sospecha la definición de rubros para la cultura es un tema casi tabú. Pero, sin duda, nos seguiremos mirando.

Mientras otros inteligentes habitantes de la convulsionada tierra miran expectantes, gracias a que el confinamiento humano les ha permitido recobrar parte de su hábitat natural. Y debe tomarse como una gran lección: el cuidado del medio ambiente o del ambiente, el respeto por la naturaleza, la salvaguardia de la fauna y la flora y en general el culto a la naturaleza hace parte hoy y mañana de la agenda de los humanos.

Pese a la incertidumbre causada por el covid19 , la fiesta, no importa sus formas, seguirá 
acompañando el imaginario social por conmemorar, recordar, celebrar, festejar o divertirse y se escenificará, como un respiro profundo, en una nación aquejada de violencias que nos parecen perennes: asesinato de líderes sociales, maltratos a la mujer, desempleo y un agudo empobrecimiento, factores que como conjunto acrecentarán la protesta social, sembrando para siempre un símbolo: el trapo rojo.

\section{Referencias}

Abadía Morales, G. (2002).ABC del Folklore Colombiano, Bogotá: Panamericana.

Baczko, B. (1979). Los Imaginarios Sociales, Buenos Aires: Nueva Visión.

Camporesi, P. (2006). El País del Hambre, México: Fondo de Cultura Económica.

Estatutos Partido Liberal Colombiano. (2011). (Pdf) Disponible en «https://www.partidoliberal.org.co/congreso/wpcontent/ uploads/2017/08/ESTATUTOS-2002-LEY-1475-DE-2011.pdf»

González Pérez, M. (2019). Fiestas de Nación en Colombia, Bogotá: Academia Colombiana de Historia.
(2020). Los Nuevos Ceremoniales en Colombia,

Bogotá: Intercultura.

. (2019). La Fiesta en Colombia. Albores del

siglo XXI. Estudios Artísticos, 5(6), 60-71. https://doi. org/10.14483/25009311.14103

Hobsbawm, E. (2000). Entrevista sobre el siglo XXI, Barcelona: Crítica.

La Ola Roja. (julio 23 de 1920). II Congreso Nacional Socialista. Popayán.

Saramago, J. (2015). "Libro de las Previsiones" en Las intermitencias de la muerte, Bogotá: Penguin Random House. Soto, J. (2017). Los diablos danzantes de Valledupar, Barranquilla: Santa Bárbara.

Prensa en línea

El Espectador «https://www.elespectador.com/»

El Tiempo «https://www.eltiempo.com/»

La Izquierda Diario MST. «www.laizquierdadiario.mx»

Publimetro «https://www.publimetro.co/co/» 